\title{
Response of seed dressing with boron dust and slurry on wheat variety WK- 1204 for grain yield and agronomic traits under poly bag and field study at Khumaltar, Nepal
}

\author{
Mina Nath Paudel \\ National Agriculture Genetic Resource Centre, Khumaltar
}

Email: mnpaudel@gmail.com

\begin{abstract}
Field and poly bag experiments were carried out at Khumaltar on wheat variety WK-1204 by dressing seed with sodium borate decahydrate dust (containing $11.34 \%$ elemental boron) and slurry per $100 \mathrm{~g}$ wheat seed. A total of nine treatments of Boron (B) dust and slurry to treat wheat seed at 2.2, 4.4, 6.4 and 8.8 gram per $100 \mathrm{~g}$ seed and basal application of $\mathrm{B}$ at $1.0 \mathrm{~kg}$ a.i./ha was in three replications for both field and poly bag experiments in randomized complete block design. The objective of the study was to find out the effect of boron seed dressing on grain yield and agronomic attributes of wheat variety under study. The result of the study revealed that grain yield and agronomic traits were highly and significantly correlated with seed dressing with boron dust at 2.2 to $8.8 \mathrm{~g}$ boron $/ 100 \mathrm{~g}$ seed of wheat. This finding was consistent with field and poly bag experiments which were coherent with the findings of lab analysis for attributes of root and shoot length, and percentage of germination. However, seed dressing with boron slurry at 2.2 to $8.8 \mathrm{~g} / 100 \mathrm{~g}$ wheat seed inhibited grain yield and agronomic attributes of wheat in the study. Therefore, seed dressing with boron dust at different level was superior over seed dressing with boron slurry for higher grain yield and yield related traits of wheat variety WK-1204 at Khumaltar condition. Boron deficiency for wheat could be corrected by seed dressing with boron dust at 2.2 to $8.6 \mathrm{~g}$ boron $/ 100 \mathrm{~g}$ wheat seed. This could be very economical and practical way of enhancing wheat production in hilly terrain areas of Nepal where one of the reasons of yield limitations is due to deficiency of boron.
\end{abstract}

Key words: seed dressing, boron dust and slurry, wheat grain yield and agronomic traits

\section{Introduction}

Boron (B), a micro nutrient, is one of the important mineral elements required for plants (Warington, 1923; Loomis \& Durst, 1992). Boron is necessary to regulate several physiological processes on plant that includes cell division, carbohydrates metabolism, and assimilate translocation together with cell wall development (Marschner, 1995; HerreraRodriguez et al; 2010, Oosterhuis, 2001; Wang et al; 2003). It has been established multifunctional role of boron by many workers not only for physiological role but also for growth and productivity of crops as well. It is reported that boron is essential for germination and growth, flowering, grain formation and other physiological process of development of young terminal florets, pollen tube development of wheat (Matoh et al; 
1992; Rerkasem and Loneragan 1994). Deficiency of boron in wheat leads to failure in fertilization, or sterility (Blevins and Lukaszewski 1998; Rerkasem and Jamjod 1997). Adverse climatic condition such as cloudy days and low or high temperature), very high soil $\mathrm{pH}$, and water logging could influence the degree of crop response to boron application in wheat (Bell and Dell 1995; Saifuzzaman 1995; Mishra et al; 1992).

Bhatta, et al (2004) reported that of the thirty-one wheat genotypes evaluated under ricewheat system in central mid hill of Nepal during the 1999 wheat growing season with and without application of boron revealed high genotypic variation in terms of sterility on wheat. They also found a clear-cut difference among genotypes in spike sterility. Same study reported a direct relation between sterility and boron minus (not applied boron) plots ranging from 1 to $100 \%$ spike sterility suggesting that boron deficiency was one of the major causes of sterility of wheat in mid hills of Nepal. The interesting finding of the study was that there was drastic reduction of sterility that ranged from $0-5 \%$ in plots that were applied boron (Bhatt, et al; 2004). Of the variety tested Achut and Annapurna-1 showed highest degree of sterility $70-80 \%$ in plots not applied boron indicating variety related response for boron as well.

Wheat is the third most important crop of Nepal with respect to area and production after rice and maize (MoAD, 2014). In 2014, area for wheat was 754474 ha with total production of $1883147 \mathrm{mt}$ and productivity of $2496 \mathrm{~kg} / \mathrm{ha}$ (MoAD, 2014). Wheat in Nepal is grown from 60-m in Terai where wheat follows rice (Paudel, 2011) and to the high hills and mountain up to 3335-m (Joshi et al; 2006). Bhatta, et al (2004) observed in mid hills of Nepal that one of major causes of sterility in wheat was due to deficiency of boron. It is very difficult to apply boron as basal application due to bulky product of boron and its location specific deficiency in the wheat growing areas in Nepal. Therefore, a cost effective method of boron application to the wheat was felt necessary to address the problem of wheat sterility due to born deficiency in the country. Most of the works related to boron application to wheat suggests a basal application of boron to correct the deficiency. In Nepal, wheat is mostly grown in the rugged hilly terrace where due to leaching and intensive cropping system there is a sporadic deficiency of nutrients including boron which has economic limitation in one hand and on the other hand commercial availability of boron for basal application is not readily accessible in a country like Nepal. It necessities that seed dressing of boron in various forms such as dust and slurry could be economically viable alternatives to address boron deficiency on wheat. There is a dearth of such study in Nepal. Hence, this study was conducted to address the issue of boron deficiency in Nepal thereby wheat productivity could be enhanced without substantially increasing cost of cultivation of wheat production. 


\section{Materials and methods}

Poly bag and field experiment were conducted in the main season (Nov/Dec 2012 and Feb/Mar 2013) wheat planting at Khumaltar in altitude of 1368-m, longitude of $85^{\circ} 20^{\prime} \mathrm{E}$, and latitude of $27^{0} 40^{\prime} \mathrm{N}$. Seed quality analysis was performed to understand quality standard of seed for treatments under study. Black poly bag of $20 \mathrm{~cm}$ dia and $60 \mathrm{~cm}$ height were used. Soils from the Agronomy Farm, Khumaltar, was filled in the poly bag leaving $20 \mathrm{~cm}$ height unfilled to irrigate the bag thereby soil in the bag is not washed out. Most popular wheat variety for mid hills WK-1204 was selected for the purpose. Wheat was planted on $25^{\text {th }}$ November 2012 both on poly bag and in the Agronomy Farm, Khumaltar. For field planting, row spacing of $25-\mathrm{cm}$ in continuous planting was done whereas for poly bag, 10 seeds per poly bag was planted. Fertilizer dose of 100:50:20 N, $\mathrm{P}_{2} \mathrm{O}_{5}$ and $\mathrm{K}_{2} \mathrm{O}$ from di-ammonium phosphate (18:46\%), urea (46\%) and muriate of potash $(60 \%)$, respectively, was applied. Half dose of $\mathrm{N}$ and full dose of $\mathrm{P}_{2} \mathrm{O}_{5}$ and $\mathrm{K}_{2} \mathrm{O}$ was applied as basal dose and remaining half dose of $\mathrm{N}$ was top dressed at dough stage of the crop. There were three replications with 9 treatments in both field and poly bag experiments randomized within each block. For field $1-\mathrm{m}^{2}$ plot for each treatment was maintained to record agronomic and phelogic data. The treatments consist of the following:

\section{Treatment details}

$\mathrm{T}_{1}: 2.5 \mathrm{~g} / \mathrm{kg}$ boron dust $=300 \mathrm{~g}$ boron per ha $=2.2 \mathrm{~g}$ sodium borate decahydrate per $100 \mathrm{~g}$ Seed

$\mathrm{T}_{2}: 5 \mathrm{~g} / \mathrm{kg}$ boron dust $=600 \mathrm{~g}$ boron per ha $=4.4 \mathrm{~g}$ sodium borate decahydrate per $100 \mathrm{~g}$ Seed

$\mathrm{T}_{3}: 7.5 \mathrm{~g} / \mathrm{kg}$ boron dust $=900 \mathrm{~g}$ boron per ha $=6.6 \mathrm{~g}$ sodium borate decahydrate per $100 \mathrm{~g}$ Seed

$\mathrm{T}_{4}: 10 \mathrm{~g} / \mathrm{kg}$ boron dust $=1200 \mathrm{~g}$ boron per ha $=8.8 \mathrm{~g}$ sodium borate decahydrate per 100 g Seed

$\mathrm{T}_{5}: 2.5 \mathrm{~g} / \mathrm{kg}$ boron slurry $=2.2 \mathrm{~g}$ sodium borate decahydrate per $100 \mathrm{~g}$ Seed

$\mathrm{T}_{6}: 5 \mathrm{~g} / \mathrm{kg}$ boron slurry $=4.4 \mathrm{~g}$ sodium borate decahydrate per $100 \mathrm{~g}$ Seed

$\mathrm{T}_{7}: 7.5 \mathrm{~g} / \mathrm{kg}$ boron slurry $=6.6 \mathrm{~g}$ sodium borate decahydrate per $100 \mathrm{~g}$ Seed

$\mathrm{T}_{8}: 10 \mathrm{~g} / \mathrm{kg}$ boron slurry $=8.8 \mathrm{~g}$ sodium borate decahydrate per $100 \mathrm{~g}$ Seed

$\mathrm{T}_{9}$ : Boron Basal Dose $(1 \mathrm{~kg}$ a.i./ha $)=9 \mathrm{~g}$ sodium borate decahydrate/plot (i.e., for $1 \mathrm{~m}^{2}$ plot)

Intercultural operation consisting of weeding and irrigation was performed for field experiment as and when necessary while for poly bag experiment on the basis of 
availability of moisture irrigation was given from sowing to maturity stage. Same set of seed treated lots of seed was analyzed on seed lab to know the effect of boron treatment on wheat seed both dust and slurry. Lab analysis for boron treated seed of wheat was done for seed testing attributes such as percentage of germination, fresh seed and diseased seed and rlength of root and shoot. Sodium borate decahydrate (Borex), commercial form of boron, available in the market that contained $11.34 \%$ elementary boron, was used for the experiments. This chemical was used as dust, slurry (making paste like structure mixing with water) and actual ingredient (a.i.) for treating wheat seed before planting and basal application of boron in the plot before planting wheat in the field. Agronomic and yield attributes of wheat were recorded from the poly bag and experiment plot in standard way as suggested by the International Centre for Wheat and Maize (CIMMYT), Mexico and National Wheat Improvement Program (NWIP), Bhirahawa, Nepal. Laboratory analysis of seed was done in the Seed Science Technology Division, Khumaltar. Recorded data were analysed by using SPSS software version 13.0.

\section{Result and discussion}

Statistical analysis of grain yield and yield related traits of wheat under poly bag study, field study and lab analysis of boron dust and slurry treated seed revealed that there was no significant difference of those traits except interaction between poly bag plant height $\mathrm{x}$ replication (Table1). This suggest that attributes such percentage of field germination and leaf chlorophyll content, LAI, root and shoot length, plant population, plant height and grain yield irrespective of poly bag, field experiment and lab analysis for wheat variety WK-1204 were not affected by the effect of seed treatment with boron dust and slurry in various compositions (Table 1 and Table 2).

Table 1. Combined ANOVA as affected by interaction between different attributes * replication of wheat variety WK-1204 for boron treated experiments, Khumaltar, Nepal

\begin{tabular}{|c|c|c|c|c|c|c|}
\hline $\begin{array}{l}\text { Interaction } \\
\text { Sources of variation }\end{array}$ & level & $\begin{array}{l}\text { Sum } \\
\text { Squares }\end{array}$ & DF & $\begin{array}{l}\text { Mean } \\
\text { Square }\end{array}$ & $\begin{array}{ll}\text { F profanity } \\
\text { level }\end{array}$ & $\begin{array}{l}\text { Significant } \\
\text { level }\end{array}$ \\
\hline $\begin{array}{l}\text { Field } \\
\text { germination*replic }\end{array}$ & $\begin{array}{l}\text { Between } \\
\text { Groups }\end{array}$ & $1,138.89$ & 3 & 379.63 & 0.74 & 0.54 \\
\hline ation & $\begin{array}{l}\text { Within Groups } \\
\text { Total }\end{array}$ & $\begin{array}{l}14,861.11 \\
16,000.00\end{array}$ & $\begin{array}{l}29 \\
32\end{array}$ & 512.45 & & \\
\hline $\begin{array}{l}\text { Poly plant } \\
\text { height*replication }\end{array}$ & $\begin{array}{l}\text { Between } \quad \text { (Combined) } \\
\text { Groups }\end{array}$ & 495.38 & 3 & 165.13 & 4.38 & 0.01 \\
\hline & $\begin{array}{l}\text { Within Groups } \\
\text { Total }\end{array}$ & $\begin{array}{l}1,092.87 \\
1,588.24\end{array}$ & $\begin{array}{l}29 \\
32\end{array}$ & 37.69 & & \\
\hline $\begin{array}{l}\text { Poly } \\
\text { chlorophyll*replic }\end{array}$ & $\begin{array}{l}\text { Between } \quad \text { (Combined) } \\
\text { Groups }\end{array}$ & 17.31 & 3 & 5.77 & 0.96 & 0.43 \\
\hline ation & $\begin{array}{l}\text { Within Groups } \\
\text { Total }\end{array}$ & $\begin{array}{l}175.24 \\
192.55\end{array}$ & $\begin{array}{l}29 \\
32\end{array}$ & 6.04 & & \\
\hline $\begin{array}{l}\text { Poly LAI * } \\
\text { replication }\end{array}$ & $\begin{array}{l}\text { Between } \quad \text { (Combined) } \\
\text { Groups }\end{array}$ & 0.20 & 3 & 0.07 & 0.96 & 0.43 \\
\hline & $\begin{array}{l}\text { Within Groups } \\
\text { Total }\end{array}$ & $\begin{array}{l}1.97 \\
2.16\end{array}$ & $\begin{array}{l}29 \\
32\end{array}$ & 0.07 & & \\
\hline $\begin{array}{l}\text { Poly root } \\
\text { length*replication }\end{array}$ & $\begin{array}{l}\text { Between } \\
\text { Groups }\end{array}$ & 480.17 & 3 & 160.06 & 2.70 & 0.06 \\
\hline
\end{tabular}




\begin{tabular}{|c|c|c|c|c|c|c|}
\hline $\begin{array}{l}\text { Interaction } \\
\text { Sources of variation }\end{array}$ & level & $\begin{array}{l}\text { Sum of } \\
\text { Squares }\end{array}$ & DF & $\begin{array}{l}\text { Mean } \\
\text { Square }\end{array}$ & $\begin{array}{l}\text { F profanity } \\
\text { level }\end{array}$ & $\begin{array}{l}\text { Significant } \\
\text { level }\end{array}$ \\
\hline & Within Groups & $1,716.19$ & 29 & 59.18 & & \\
\hline & Total & $2,196.36$ & 32 & & & \\
\hline $\begin{array}{l}\text { Lab root } \\
\text { length*replication }\end{array}$ & $\begin{array}{l}\text { Between } \\
\text { Groups }\end{array}$ & 0.69 & 3 & 0.23 & 0.01 & 1.00 \\
\hline & Within Groups & 916.01 & 32 & 28.63 & & \\
\hline & Total & 916.70 & 35 & & & \\
\hline $\begin{array}{l}\text { Lab shoot } \\
\text { length*replication }\end{array}$ & $\begin{array}{l}\text { Between } \\
\text { Groups }\end{array}$ & 1.44 & 3 & 0.48 & 0.08 & 0.97 \\
\hline & Within Groups & 195.99 & 32 & 6.12 & & \\
\hline & Total & 197.43 & 35 & & & \\
\hline $\begin{array}{l}\text { Field plant } \\
\text { population*replicat }\end{array}$ & $\begin{array}{l}\text { Between } \quad \text { (Combined) } \\
\text { Groups }\end{array}$ & $2,818.67$ & 2 & $1,409.33$ & 0.25 & 0.78 \\
\hline & $\begin{array}{l}\text { Within Groups } \\
\text { Total }\end{array}$ & $\begin{array}{l}136,278.00 \\
139,096.67\end{array}$ & $\begin{array}{l}24 \\
26\end{array}$ & $5,678.25$ & & \\
\hline $\begin{array}{l}\text { Field plant height } \\
\text { *replication }\end{array}$ & $\begin{array}{l}\text { Between } \quad \text { (Combined) } \\
\text { Groups }\end{array}$ & 32.66 & 2 & 16.33 & 0.95 & 0.40 \\
\hline & $\begin{array}{l}\text { Within Groups } \\
\text { Total }\end{array}$ & $\begin{array}{l}412.84 \\
445.50\end{array}$ & $\begin{array}{l}24 \\
26\end{array}$ & 17.20 & & \\
\hline $\begin{array}{l}\text { Field chlorophyll } \\
\text { *replication }\end{array}$ & $\begin{array}{l}\text { Between } \quad \text { (Combined) } \\
\text { Groups }\end{array}$ & 2.17 & 2 & 1.09 & 0.29 & 0.75 \\
\hline & $\begin{array}{l}\text { Within Groups } \\
\text { Total }\end{array}$ & $\begin{array}{l}89.00 \\
91.17\end{array}$ & $\begin{array}{l}24 \\
26\end{array}$ & 3.71 & & \\
\hline $\begin{array}{l}\text { Field LAI * } \\
\text { replication }\end{array}$ & $\begin{array}{l}\text { Between } \quad \text { (Combined) } \\
\text { Groups }\end{array}$ & 0.35 & 2 & 0.18 & 0.95 & 0.40 \\
\hline & $\begin{array}{l}\text { Within Groups } \\
\text { Total }\end{array}$ & $\begin{array}{l}4.44 \\
4.79\end{array}$ & $\begin{array}{l}24 \\
26\end{array}$ & 0.19 & & \\
\hline $\begin{array}{l}\text { Field grain yield } \\
\mathrm{g} / \mathrm{m}^{2} * \text { replication }\end{array}$ & $\begin{array}{l}\text { Between } \\
\text { Groups }\end{array}$ & $54,521.94$ & 2 & $27,260.97$ & 0.73 & 0.49 \\
\hline & $\begin{array}{l}\text { Within Groups } \\
\text { Total }\end{array}$ & $\begin{array}{l}901,542.56 \\
956,064.50\end{array}$ & $\begin{array}{l}24 \\
26\end{array}$ & $37,564.27$ & & \\
\hline
\end{tabular}

Table 2. ANOVA for grain yield and yield attributes of wheat variety WK-1204 for boron treated field experiment, Khumaltar, Nepal

\begin{tabular}{|c|c|c|c|c|c|c|}
\hline \multicolumn{2}{|c|}{ Attributes/ Source of variation } & \multirow{2}{*}{$\begin{array}{l}\begin{array}{l}\text { Sum } \\
\text { Squares }\end{array} \\
2818.667\end{array}$} & \multirow{2}{*}{$\frac{\text { DF }}{2}$} & \multirow{2}{*}{$\begin{array}{l}\text { Mean } \\
\text { Square } \\
1409.333\end{array}$} & \multirow{2}{*}{$\begin{array}{l}\text { F } \\
\text { value } \\
0.248\end{array}$} & \multirow{2}{*}{$\begin{array}{l}\begin{array}{l}\text { Significant } \\
\text { level }\end{array} \\
0.782\end{array}$} \\
\hline Plant population $/ \mathrm{m}^{2}$ & Between Groups & & & & & \\
\hline & Within Groups & 136278.000 & 24 & 5678.250 & & \\
\hline & Total & 139096.667 & 26 & & & \\
\hline \multirow[t]{3}{*}{ Plant height $(\mathrm{cm})$} & Between Groups & 32.661 & 2 & 16.330 & 0.949 & 0.401 \\
\hline & Within Groups & 412.836 & 24 & 17.201 & & \\
\hline & Total & 445.496 & 26 & & & \\
\hline \multirow{3}{*}{$\begin{array}{l}\text { Leaf chlorophyll } \\
\text { content }(\%)\end{array}$} & Between Groups & 2.172 & 2 & 1.086 & 0.293 & 0.749 \\
\hline & Within Groups & 88.997 & 24 & 3.708 & & \\
\hline & Total & 91.169 & 26 & & & \\
\hline \multirow[t]{3}{*}{ Leaf area index } & Between Groups & .351 & 2 & .175 & 0.948 & 0.402 \\
\hline & Within Groups & 4.443 & 24 & .185 & & \\
\hline & Total & 4.794 & 26 & & & \\
\hline \multirow[t]{3}{*}{ Grain yield gram $/ \mathrm{m}^{2}$} & Between Groups & 54521.937 & 2 & 27260.969 & 0.726 & 0.494 \\
\hline & Within Groups & 901542.564 & 24 & 37564.274 & & \\
\hline & Total & 956064.502 & 26 & & & \\
\hline
\end{tabular}


Bivariate correlation of grain yield and agronomic traits for field experiment indicated that the relationship between plant height $\mathrm{x}$ plant population, LAI x plant population, and grain yield $x$ plant population, LAI $x$ plant height were positively highly significant whereas relationship between grain yield $x$ LAI was positively significant (Table 3). Contrary to this the relationship between percentage leaf chlorophyll content $\mathrm{x}$ plant population, plant height, LAI, and grain yield $/ \mathrm{m}^{2}$ were negatively related (Table 3). The study exhibited that seed dressing of wheat with boron dust and slurry in different combinations could result highly positive and negative (not significant) relationship on grain yield and agronomic traits of wheat variety WK-1204 under study.

Table 3. Bivariate correlation coefficient for grain yield and yield attributes of wheat variety WK-1204 under boron treated field experiment, Khumaltar, Nepal $(\mathrm{N}=27)$

\begin{tabular}{|c|c|c|c|c|c|}
\hline Attributes & $\begin{array}{l}\text { Plant } \\
\text { population/ } \\
\mathbf{m}^{2}\end{array}$ & $\begin{array}{l}\text { Plant } \\
\text { height } \\
(\mathrm{cm})\end{array}$ & $\begin{array}{l}\text { Leaf } \\
\text { chlorophyll } \\
\text { Content }(\%)\end{array}$ & $\begin{array}{l}\text { Leaf } \\
\text { area } \\
\text { Index }\end{array}$ & $\begin{array}{l}\text { Grain } \\
\text { yield } \\
\text { gram } / \mathrm{m}^{2}\end{array}$ \\
\hline Plant population $/ \mathrm{m}^{2}$ & 1.0 & & & & \\
\hline Plant height $(\mathrm{cm})$ & $0.778(* *)$ & 1.0 & & & \\
\hline $\begin{array}{l}\text { Leaf chlorophyll content } \\
\text { (\%) }\end{array}$ & -0.021 & -0.201 & 1.0 & & \\
\hline Leaf area index & $0.670(* *)$ & $0.498(* *)$ & -0.024 & 1.0 & \\
\hline Grain yield gram $/ \mathrm{m}^{2}$ & $0.860(* *)$ & $0.811(* *)$ & -0.108 & $0.484(*)$ & 1.0 \\
\hline
\end{tabular}

Seed dressing with boron dust at 2.2 to $8.8 \mathrm{~g} / 100$ seed showed that plant population $/ \mathrm{m}^{2}$ indicating effectiveness of boron seed dressing in the field study (Fig. 1). For those treatments of T1 to T4 plant population and plant height also followed same pattern as that of grain yield of highly significant indicating that seed dressing of boron for wheat seed was effective compared to seed dressing with boron slurry with respect to these traits. Percentage of leaf chlorophyll content was not affected due to the effect of wheat seed treatment with boron dust and slurry. Basal application of boron was inferior to seed dressing with dust affecting these traits under study. Therefore, it is obvious that seed treatment of wheat with boron dust at 2.2 to $8.8 \mathrm{~g} / 100$ seed was found effective than that of seed treatment with boron slurry and basal application of boron to correct boron deficiency in the wheat under Khumaltar condition, Nepal. 


\section{Treatment details}

T1:Seed trearment@2.2 g sodium borate decahydrate (SBDH) /100 g seed

$\mathrm{T}_{2}$ : Seed treatment @4.4 g SBDH /100 g Seed

$\mathrm{T}_{3}$ : Seed treatment @6.6 g SBDH/100 g Seed

$\mathrm{T}_{4}$ : Seed treatment @8.8 g SBDH/100 g Seed

$\mathrm{T}_{5}$ :Seed treatment @ $2.2 \mathrm{~g}$ sodium borate decahydrate slurry (SBDHS)/ $100 \mathrm{~g}$ Seed

$\mathrm{T}_{6}$ : Seed treatment @4.4 g SBDHS/ $100 \mathrm{~g} \mathrm{Seed}$

$\mathrm{T}_{7}$ : Seed treatment @6.6 g SBDHS/ $100 \mathrm{~g} \mathrm{Seed}$

$\mathrm{T}_{8}$ : Seed treatment @8.8 g SBDHS/ $100 \mathrm{~g}$ Seed

$\mathrm{T}_{9}$ : Basal application of SBDH @ $1 \mathrm{~kg}$ a.i./ha

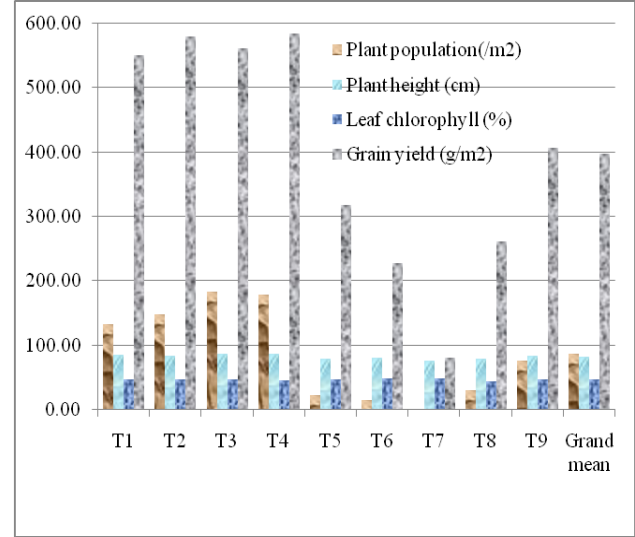

Fig. 1 Grain yield and yield attributes of wheat variety WK-1204 as affected by different seed treatment procedure of boron at Agronoy Farm, Khumaltar

Laboratory analysis of root, length, shoot length and percent germination of wheat seed treated with boron duct at 2.2 to $8.8 \mathrm{~g} / 100$ seed of WK-1204 vareiety of wheat exhibited high response of these attributes compared to boronn slurry treateed seed and basal apllicaaion of boron in the study (Fig.2). This pattern was consistent with the field study for for germination as indicated in the fiedl experiment (Fig.1). From lab and field study of seed treatment with boron dust it is inferred that seed treatment with boron dust is superior over seed treatment with boron slurry and basal apllication of boron from the the sodium borate decahydrate containing $11.34 \%$ elemental boron.

\section{Treatment details}

T1:Seed trearment@2.2 g sodium borate decahydrate (SBDH) $/ 100 \mathrm{~g}$ seed

$\mathrm{T}_{2}$ : Seed treatment @4.4 g SBDH /100 g Seed

$\mathrm{T}_{3}$ : Seed treatment @6.6 g SBDH/100 g Seed

$\mathrm{T}_{4}$ : Seed treatment @8.8 g SBDH/ $100 \mathrm{~g}$ Seed

$\mathrm{T}_{5}$ :Seed treatment @ $2.2 \mathrm{~g}$ sodium borate decahydrate slurry (SBDHS)/ $100 \mathrm{~g}$ Seed

$\mathrm{T}_{6}$ : Seed treatment @4.4 g SBDHS/ $100 \mathrm{~g}$ Seed

$\mathrm{T}_{7}$ : Seed treatment @6.6 g SBDHS/ $100 \mathrm{~g}$ Seed

$\mathrm{T}_{8}$ : Seed treatment @8.8 g SBDHS/ $100 \mathrm{~g}$ Seed

$\mathrm{T}_{9}$ : Basal application of SBDH @ $1 \mathrm{~kg}$ a.i./ha

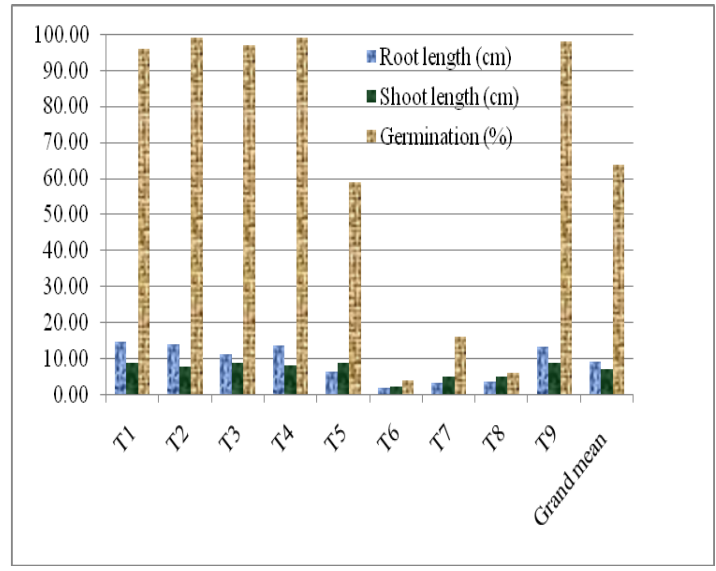

Fig. 2 Laboratory analysis of wheat seed WK-1204 as affected by different seed treatment procedure of boron at Khumaltar

Same pattern of enhanced in the percentage of germination and leaf chlorophyll content, and increased in plant height and root length was obseerd for seed dressing with boron 
dust ranging from 2.2 to $8.8 \mathrm{~g} / 100$ seed for wheat variety WK-1204 under poly bag study (Fig. 3). From field study, lab analysis and poly bag study of seed dressing with boron dust and slurry and basal apllication in the field it could be anecdotal that boron deficiency in wheat could be corrected through seed dressing of boron at 2.2 to $8.8 \mathrm{~g} / 100$ seed of wheat. This amount of boron for seed dressing is remarkebly superior over same quantity of slurry for seed treatment and basal application of boron at $1.0 \mathrm{~kg}$ a.i. per hectare.

Inhibition of germination, root and shoot length, LAI and grain yield of wheat with seed treated with boron slurry could be be the result of toxicity of born to the embroyo due to its high moisture and immediate contact of seed with boron that is intact with seed coat compared to dust aplication of born for seed dressing. Another reason for negative effect of boron slurry for seed treatment of wheat could be the direct contact of boron with root, shoot and seed compared to boron dust which could be available to the wheat plant in later stages of growth when wheat plant could absorb boron as it passes to late vagetative and reproductive phase in which there could be high demand of boron from the plant as well.

\section{Treatment details}

T1:Seed trearment@2.2 g sodium borate decahydrate (SBDH) /100 g seed

$\mathrm{T}_{2}$ : Seed treatment @4.4 g SBDH /100 g Seed

$\mathrm{T}_{3}$ : Seed treatment @6.6 g SBDH/100 g Seed

$\mathrm{T}_{4}$ : Seed treatment @8.8 g SBDH/100 g Seed

$\mathrm{T}_{5}$ :Seed treatment @ $2.2 \mathrm{~g}$ sodium borate decahydrate slurry (SBDHS)/ $100 \mathrm{~g}$ Seed

$\mathrm{T}_{6}$ : Seed treatment @4.4 g SBDHS/ $100 \mathrm{~g}$ Seed

T7 : Seed treatment @6.6 g SBDHS/ $100 \mathrm{~g}$ Seed

$\mathrm{T}_{8}$ : Seed treatment @8.8 g SBDHS/ $100 \mathrm{~g}$ Seed

$\mathrm{T}_{9}$ : Basal application of SBDH @ $1 \mathrm{~kg}$ a.i./ha

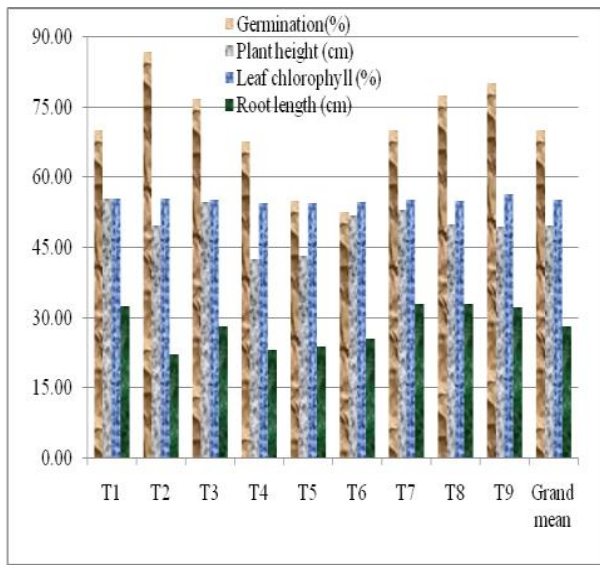

Fig. 3 Agronomic attributes of wheat variety WK-1204 as affected by different seed treatment procedure of boron under poly bag experiment at Khumaltar

Results obtained from these experiments showed that contribution of boron on grain yield and yield related attributes of wheat could be partly explained by the use of boron despite the fact that grain yield is a complex character that results from contribution of several plant parameters. Grain yield and yield related parameter of wheat are interrupted by boron deficiency and it is possible to overcome this problem by the application of B to the soil (Debnath, et al; 2011). There are cases that B deficiency in wheat and other crops could be corrected by seed dressing. However, despite the many methods applied to correct micronutrient deficiency in the soil and foliar application is one of the most prevalent methods of micronutrient correction. The cost involved and difficulty in obtaining high 
quality micronutrient fertilizers are major concerns in developing countries for poor farmers (Farooq et al; 2012). Rahman et al (2014) have reported seed priming with micronutrient in different concentration were attractive and easy alternatives to address micronutrient deficiency for chickpea. They have tested different concentration of boron and molybdenum for seed priming of chick pea in Bangladesh and found that seed treatment with $2.0 \mathrm{~g} \mathrm{~B}$ and $1.0 \mathrm{~g}$ Mo along with 40-30-40-20- $0.2 \mathrm{~kg} \mathrm{~N}-\mathrm{P}-\mathrm{K}-\mathrm{S}$ and $\mathrm{Zn} / \mathrm{ha}$ gave higher seed yield of $119.6 \mathrm{~kg} / \mathrm{ha}$ and $96 \%$ germination of chick pea in the study. In Pakistan, contrary to this finding, seed priming with boron solution (1, 1.5 and $2 \%$ ) inhibited the germination of carrot seed whereas same percentage of solution of seed priming with $\mathrm{Zn}$ and $\mathrm{Mn}$ induced the highest emergence percentage, vigor index and highest mean shoot and root length of the carrot in the study (Muneeb et al; 20113). Therefore, seed priming for micro nutrients depends upon types of crops and concentration of micro nutrient. Our finding supports the enhanced grain yield and agronomic attributes of wheat when seed dressing was done with different concentration of boron dust. In Chaing Mai, Thailand, study revealed that the effect of B was by far the largest on grain set of wheat (Rarkasem et al; 1994).

\section{Acknowledgements}

Field experiment was conducted in the Agronomy Farm of the Agronomy Division, poly bag experiment was maintained under the premise of the National Agricultural Research Institute complex and lab analysis of seed was done at the Seed Science Technology Research Division, Khumaltar, NARC. Help provided for recording data by Mr. AP Paudel and Mr. RK Bhattarai, Scientist under the Outreach Research Division and Agronomy Division, NARC, is highly appreciated.

\section{References}

Bhatta, MR; GO Ferrara ; E Duveiller ; and S Justice. 2004. Wheat sterility induced by boron deficiency in Nepal. In Micronutrients in South and South East Asia: Proceedings of an International Workshop held in Kathmandu, Nepal, 8-11 September, 2004 (eds.) Andersen, P; Tuladhar, J K; Karki, K B and Maskey, S.L. pp 221-229.

Blevins, DG and KM Lukaszewski. 1998. Boron in plant structure and function. Annual Review of Plant Physiology and Molecular Biology, 49: 481-500.

Debnath, MR; M Jahiruddin; MM Rahman; and M A, Haque. 2011. Determining optimum rate of boron application for higher yield of wheat in Old Brahmaputra Floodplain soil. J. Bangladesh Agril. Univ. 9: 205-210.

Farooq, M; AWahid; and KHM, Siddique. 2012. Micronutrient application through seed treatments - a review. J. of Soil Sci. and Plant Nutrition. 12: 125-142. 
Herrera-Rodriguez, MB; A Gonzalez-Fontes; J Rexach; JJ CamachoCristobal; JM Maldonado and MT, Navarro-Gochicao. 2010. Role of boron in vascular plants and response mechanism to boron stresses. Plant Stress, 4: 115-122

Joshi, BK; AK Mudwari; and MR Bhatta.2006. Wheat Genetic Resources in Nepal. Nepal Agric. Res. J., 7:1-9.

Loomis, WD; and RW Durst. 1992. Chemistry and biology of boron. Biol. Factors, 3: 229-239

Marschner, H., 1995. Mineral Nutrition of Higher Plants. 2nd edition, p: 889. Academic Press, New York, USA

Matoh, T; K Ishagaki; M Mizutani; W Matsunaga; and K Takabe. 1992. Boron nutrition of cultured tobacco BY-2 cells: I. Requirement for and intracellular localization of boron and selection of cells that tolerate low levels of boron. Plant Cell Physiology. 33: 1135-41.

Mishra, R; RC Munankarmi; SP Pandey; and PR Hobbs. 1992. Sterility in wheat at Tarahara in the Eastern Terai of Nepal. In Mann, CE; Rerkasem, B (eds) Boron deficiency in wheat, Wheat Special Report No. 11, pp. 65-71. El Batan (Mexico): CIMMYT.

MoAD (Ministry of Agriculture Development). 2014. Agriculture Statistics of Nepal. MoAD, Singhadurbar, Nepal.

Muneeb, M; M Ikram; M Iqbal; MM Raza1; S Habib; G Hammad; M Najeebullah; M Saleem and R Ashraf. 2013. Effect of seed priming with zinc, boron and manganese on seedling health in carrot (Daucus carota L.), Int. J. of Agric. and Crop Sci.5-22. (online) at www.ijagcs.com

Oosterhuis, DM. 2001. Physiology and nutrition of high yielding cotton in the USA, pp: 18-24. In Informacoes Agronomicas N-Setembro.

Paudel, MN. 2011. Rice (Oryza sativa L.) cultivation in the highest elevation in the world. Agronomy J. Nepal. 2:31-41.

Rahman, MS; MN Islam; MR Shaheb; MA Arafat; PC Sarker; and MH Sarker. 2014. Effect of seed treatment with boron and molybdenum on the yield and seed quality of chickpea. Int. J. Expt. Agric. (Online). 4: 1-6.

Rerkasem, B ; and S Jamjod. 1997. Genotypic variation in plant response to low boron and implication for plant breeding. In Dell, B; Brown, PH; Bell, RW (eds) Boron in soils and plants: reviews, proceedings of the International Symposium on Boron in Soils and Plants, Chiang Mai, Thailand, 7-11 September, 1997, pp. 169-180. Dordrecht: Kluwer Academic Publishers.

Rerkasem, B; S Moolsrit; J Pant; and S Lordkaew. 1994. Effects of Boron, Planting Date and Genotype on Sterility in Wheat in Thailand. Retrieved on 19 Nov 2015. http://aciar.gov.au/files/node/2220/sterility_in_wheat_in_subtropical_asia_part_4_19 694.pdf 
Rerkasem, B; and J Loneragan,. 1994. Boron deficiency in two wheat genotypes in a warm, subtropical region. Agronomy Journal, 86: 887-90.

Saifuzzaman, M. 1995. Sterility in wheat in Bangladesh. In Bell, RW; Rerkasem, B (eds) Causes of sterility in wheat, proceedings of a workshop held at Chiang Mai, Thailand, 25-26 July 1994, Environmental Science Report 94/6, pp 57-72. Murdoch (Australia): Murdoch University.

Siddiky, MA; NK Halder; KU Ahammad; K Anam; and M Rafiuddin. 2007. Response of brinjal to zinc and boron fertilization. Int. J. Sustain. Agric. Technol. 3: 40-45

Wang, Q., LU Longdou; WU Xiaoqin; LI Yiqin; and LIN Jinxing. 2003. Boron influences pollen germination and pollen tube growth in Picea meyeri. Tree Physiol. 23: 345351 .

Warington, K. 1923. The effect of boric acid and borax on the broad bean and certain other plants. Annl. Bot. 37: 457-466. 